\title{
Analysis of Namangan 77 cotton in production line with different saw gins for short fiber yield
}

\author{
Shuhrat Azizov ${ }^{1, *}$, Farhod Uzoqov ${ }^{1}$, Mirshoroffiddin Mirzakarimov ${ }^{1}$, and Oybek Usmanov ${ }^{1}$ \\ ${ }^{1}$ Namangan Institute of Engineering and Technology ${ }^{1}$ str. Kasansay 7, Namangan, 160115, \\ Uzbekistan
}

\begin{abstract}
For the accuracy of the results, the study was carried out for three years. The average of each factory gins was chosen. Comparison of fiber properties processed in different cotton processing plants, with different models of fiber separators. Each sample of fiber grade 1 Namangan 77 raw cotton was obtained as a result of ginning with such factory gins 4DP-130.5 DP-130, 3HDD and Lummus gins in Namangan region. The Fiber properties of all samples were measured with the Advanced HVI Fiber Information System, to determine the yield of short fibers. The main purpose of the study is to determine which model of sawing gin to produce more short fibers. For next modernization working parts of other model gin for increasing quality of fiber.
\end{abstract}

\section{Introduction}

At primary cotton processing plants in Uzbekistan, cotton is usually collected from the bunt by a mechanical picker or stripper, transported in a pneumatic module and transferred to technological chain through a sequence of processes including drying, cleaning, ginning, lint cleaning, and bale packing. Some of these processes change various properties of cotton. The cotton fibers offered for sale are selected and modified in accordance with the standards (HVI). Standards (HVI) for fiber are set by the joint-stock company SIFAT in Uzbek standard to determine the properties of fiber, such as color, length, microneyr, strength, and trash content, which are important in textile processing.. Fiber quality is an important aspect of cotton research, and the fiber must be removed from the seed to determine its bulk properties.

American scientists have conducted research on the comparison of factory and laboratory gins since the differences between laboratory gins and production gins have not been studied. Their research proved that the results obtained from laboratory gins could not be accurately reproduced, even with a correction factor, in production gins of cotton processing plants. [1,2]

But the correlation Analysis indicated that the experimental gin, close to factory parameters, withstands lint production samples that were the most similar to lint production samples, considering all properties. These results show that factory-close experimental laboratory gins offer an effective, convenient screening tool for cotton researchers predicting fiber quality in production gins. Using this data, we determined our way of conducting the research. [3,4]

\footnotetext{
*Corresponding author: azizovshuhrat@gmail.com
} 


\section{Methods}

The purpose of this study was to compare the quality of fiber to analyze cotton plants in the Namangan region with different types of gins and their working parts that contribute to the output of short fiber. Determining the optimal parameters of the working parts of the gin to modeling the quality of the fiber.[5,6]

To begin with, we conducted a statistical analysis after receiving data from the company SIFAT on cotton fiber of the grade - 1 Namangan 77 harvest of 1st year of research, 2nd year of research, 3rd year of research the main indicator we took is the yield of short fibers.

SFI-index of short fibers, or the number of fibers in the measured sample that are less than 0.5 inches long \%. after receiving the data on the table, we displayed them in graphical order to determine the properties and factors that affect the quality of the fiber during saw ginning.[7-9]

Table 1. Statistics of 1st year research on the quality of cotton fiber on Namangan 77, grade -1 .

\begin{tabular}{|l|l|l|l|}
\hline $\begin{array}{l}\text { Names of cotton } \\
\text { processing plants }\end{array}$ & $\begin{array}{l}\text { Average in } \\
\text { IBLENGTH }\end{array}$ & Average in SFI & $\begin{array}{l}\text { Average } \\
\text { STRENGTH }\end{array}$ \\
\hline 3028 Pap & 111.9523 & 4.19351 & 31.59734 \\
\hline 3041 Uychi & 112.600 & 3.813758 & 33.92539 \\
\hline 3042 Namangan 3 & 112.5114 & 4.000455 & 30.17477 \\
\hline 3043 Tashbulak & 112.7144 & 3.761403 & 33.15875 \\
\hline 3044 Norin & 112.5878 & 3.687161 & 33.60263 \\
\hline 3046Chust & 112.5576 & 3.619007 & 33.14875 \\
\hline 3047 Uchkurgan & 112.4583 & 3.847357 & 33.34615 \\
\hline 3048 Gulbax & 112.3386 & 4.296065 & 32.20291 \\
\hline 3049 Chartak & 112.4991 & 3.976447 & 33.78364 \\
\hline 3050 Kasan & 111.7887 & 4.180011 & 31.18185 \\
\hline 3051 Mirishkor & 113.6079 & 3.623138 & 33.94058 \\
\hline
\end{tabular}

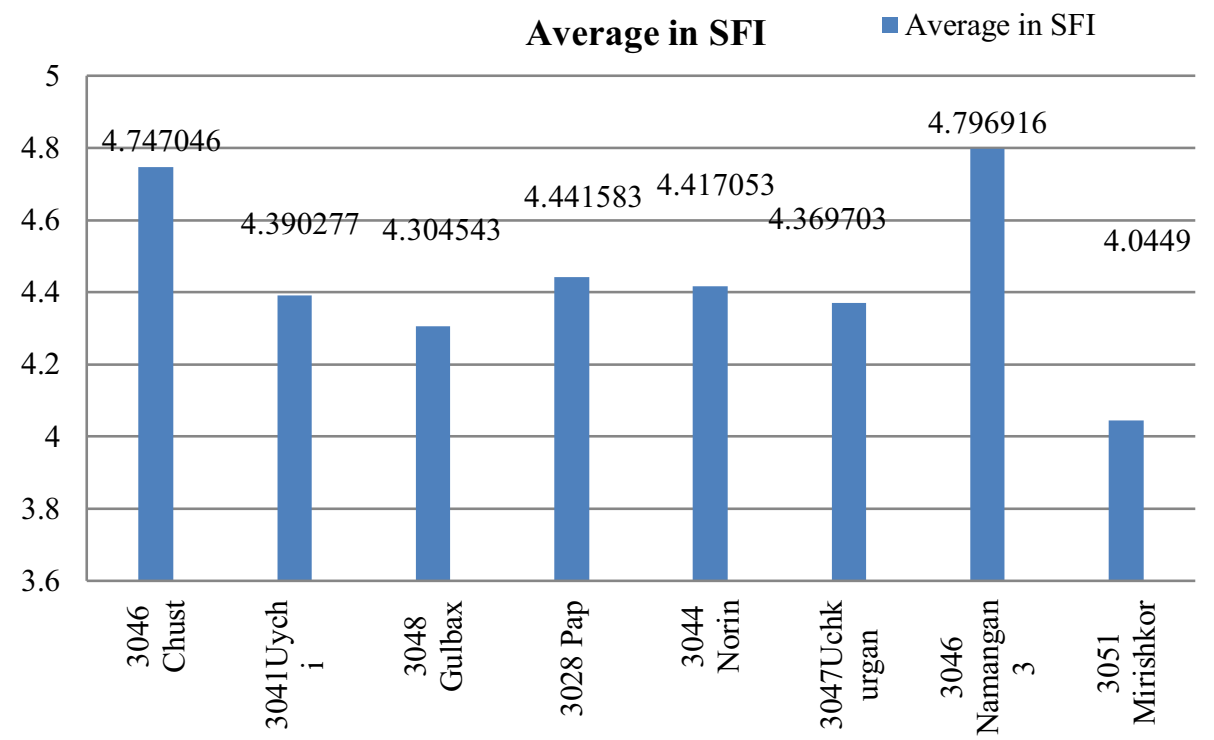

Fig. 1. Statistics of 1 st year research on the quality of cotton fiber on Namangan 77, grade. -1 . 
A statistical study of 1st year showed that this graph showed that the lowest SFI - index of short fibers at The Mirishkor cotton plant and makes up 3.62\% of the total weight of cotton. [10] For short fibers, SFI is the index of short fibers, or the number of fibers in the measured sample that are less than 0.5 inches long, $\%$. And the highest yield of short fibers is at the Gulbax plant and is $4.30 \%$

Table 2. Statistics of 2 nd year research on the quality of cotton fiber on Namangan77, grade 1.

\begin{tabular}{|c|c|c|c|}
\hline $\begin{array}{c}\text { Names of cotton } \\
\text { processing plants }\end{array}$ & $\begin{array}{c}\text { Average in } \\
\text { FIBLENGTH }\end{array}$ & Average in SFI & $\begin{array}{c}\text { Average in } \\
\text { STRENGTH }\end{array}$ \\
\hline 3028 Pap & 112.1342 & 4.854719 & 32.03274 \\
\hline 3041 Uychi & 112.2726 & 4.83333 & 32.32988 \\
\hline 3043 Tashbulak & 112.6256 & 4.840825 & 31.98049 \\
\hline 3044Norin & 112.3186 & 5.075446 & 32.67889 \\
\hline 3046 Chust & 112.4721 & 5.488028 & 32.44607 \\
\hline 3047 Uchkurgan & 112.1036 & 5.145151 & 32.67528 \\
\hline 3048 Gulbax & 112.3562 & 5.276708 & 31.86648 \\
\hline 3049 Chartak & 112.4755 & 5.101204 & 32.92095 \\
\hline 3050 Kasan & 111.6537 & 5.157461 & 31.66534 \\
\hline 3051Mirishkor & 113.4279 & 4.569797 & 32.48395 \\
\hline
\end{tabular}

Average in SFI $\quad$ Average in SFI

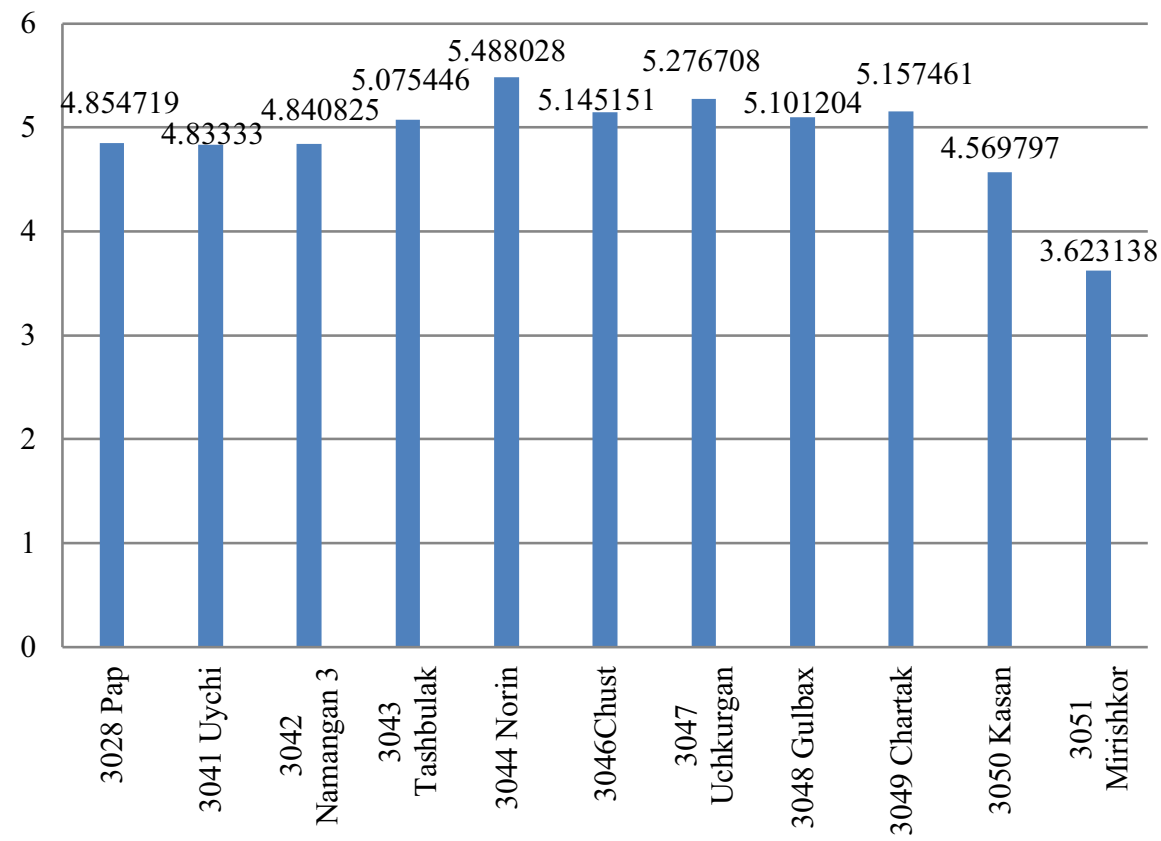

Fig. 2. Statistics of 2 nd year research on the quality of cotton fiber on Namangan 77 , grade -1 indicators by plants.

2-year statistical study has shown that the lowest SFI - index of short fibers at Mirishkor cotton plant is $4.57 \%$ of the total weight of cotton. [11] And the highest yield of short fibers is $5.49 \%$ at Chust plant. 
Table 3. Statistics of 3 - year research on the quality of cotton fiber on Namangan 77.

\begin{tabular}{|c|c|c|c|}
\hline $\begin{array}{c}\text { Names of cotton } \\
\text { processing plants }\end{array}$ & $\begin{array}{c}\text { Average in } \\
\text { FIBLENGTH }\end{array}$ & $\begin{array}{c}\text { Average in } \\
\text { SFI }\end{array}$ & $\begin{array}{c}\text { Average in } \\
\text { STRENGTH }\end{array}$ \\
\hline 3046 Chust & 112.5192 & 4.747046 & 33.75442 \\
\hline 3041Uychi & 112.4293 & 4.390277 & 34.80671 \\
\hline 3048 Gulbax & 112.6788 & 4.304543 & 33.76084 \\
\hline 3028 Pap & 112.5627 & 4.441583 & 33.87558 \\
\hline 3044 Norin & 112.5782 & 4.417053 & 33.6169 \\
\hline 3047Uchkurgan & 112.4004 & 4.369703 & 33.51503 \\
\hline 3046 Namangan 3 & 112.4591 & 4.796916 & 32.97717 \\
\hline 3051 Mirishkor & 112.7977 & 4.0449 & 35.44845 \\
\hline
\end{tabular}

Average in SFI $\quad$ Average in SFI

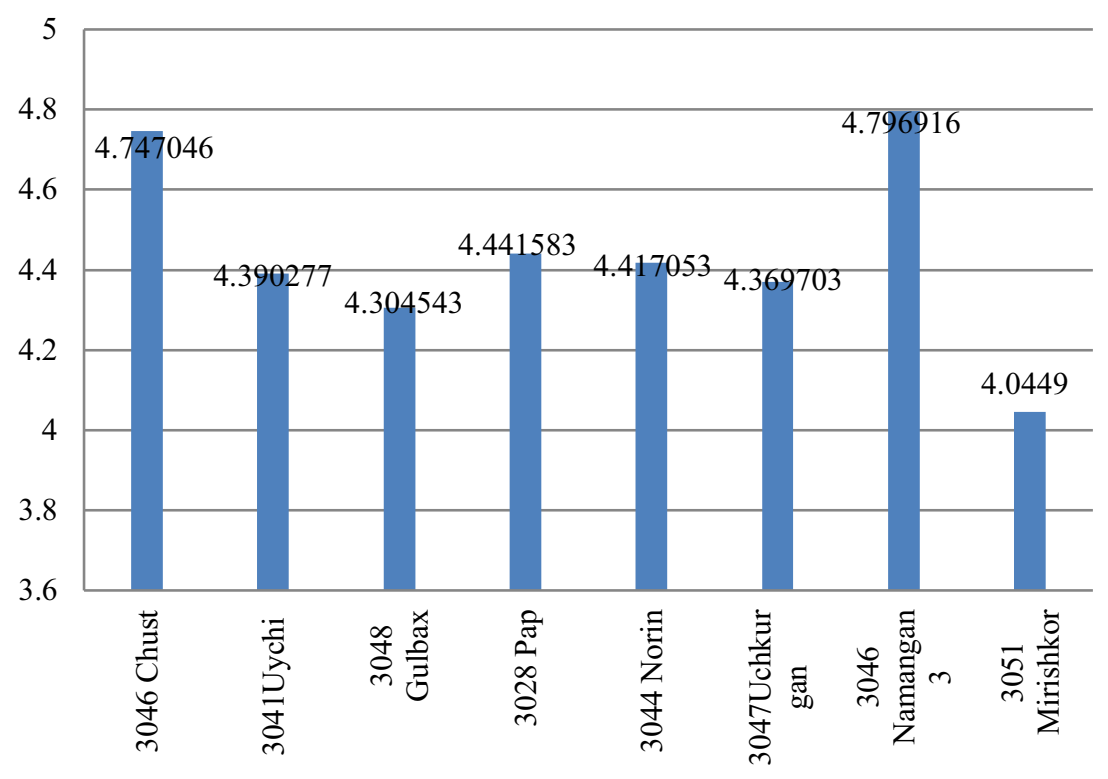

Fig. 3. Statistics of 2 nd year research on the quality of cotton fiber on Namangan 77 , grade -1 indicators by plants.

A statistical study of 3-year has shown that the lowest SFI - index of short fibers at the Mirishkor cotton mill and it makes $4.04 \%$ of the total weight of cotton. [12,13] And the highest yield of short fibers is $4.80 \%$ at the Namangan 3 plant.

\section{Results}

The results obtained from the production gins of cotton processing plants showed that the lowest SFI - index of short fibers at Mirishkor cotton plant, which uses an American-made Lummus fiber separator, the average value for three-year period is $4.07 \%$ of the total weight of raw cottons. In second place, the Uychi cotton plant average value for three years is SFI $4.34 \%$ of the total weight of cotton that uses fiber separators 4 DP -130 .

Further analysis of the spinning industry that purchased raw materials from cotton fiber manufacturers showed the following results.Quality indicators on a single yarn such as thick 
(THICK $+50 \%$ ) and neps (NEPS $+200 \%$ ) are relatively high for Lots of fibers Lot -2 and Lot -3 than Lot-1. According to Uster statistics -2001 , the yarn produced by Lot-1 cotton fiber showed better results. This is due to the fact that the Lot- 1 batch of cotton fiber accepted a fiber with the presence of short fibers in the limit of $4.07 \%$ and a yarn yield is $88 \%$ per 100 tons of cotton fiber. And on Lot- 2 and Lot-3, the presence of short fiber content in the limit of $4.34 \%$ and $4.63 \%$, yarn yield is $86.5 \%$ and $85.7 \%$ respectively per 100 tons of fiber cotton. (Table 4).

Table 4. Statistics of Yarn output from fiber Namangan 77.

\begin{tabular}{|l|c|c|c|c|c|}
\hline $\begin{array}{c}\text { The batch } \\
\text { number of the } \\
\text { cotton fiber }\end{array}$ & $\begin{array}{c}\text { The } \\
\text { content } \\
\text { of the } \\
\text { short } \\
\text { fibers, \% }\end{array}$ & $\begin{array}{c}\text { Yarn } \\
\text { output } \\
\text { from the } \\
\text { fiber, \% }\end{array}$ & $\begin{array}{c}\text { Trash } \\
\text { particles } \\
\text { in fiber, \% }\end{array}$ & $\begin{array}{c}\text { Invisible } \\
\text { trash, \% }\end{array}$ & $\begin{array}{c}\text { Profit, } \\
\text { USD }\end{array}$ \\
\hline $\begin{array}{l}\text { LOT 1- 3051 } \\
\text { Mirishkor }\end{array}$ & 4.07 & 88 & 5,73 & 2,2 & 286600 \\
\hline $\begin{array}{l}\text { LOT2- 3041 } \\
\text { Uychi }\end{array}$ & 4.34 & 86,5 & 6,86 & 2,3 & 273600 \\
\hline $\begin{array}{l}\text { LOT3- } \\
\text { 3048Gulbax }\end{array}$ & 4.62 & 85,7 & 7,28 & 2,4 & 264020 \\
\hline
\end{tabular}

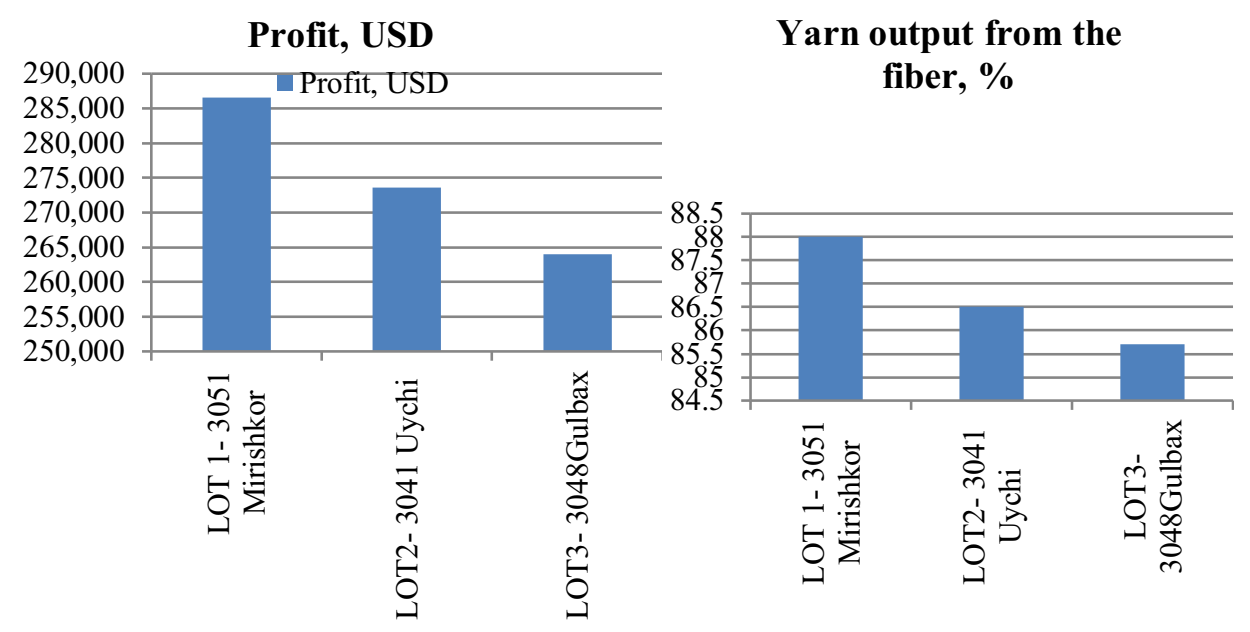

Fig. 4. Statistics of Yarn profit and output from fiber Namangan 77.

\section{Conclusions}

The cost of raw materials represents more than $60 \%$ of the total cost of production in most spinning factories. This situation forces factory managers to have an excellent knowledge of raw materials and the correct choice of raw materials determines many reasons.

In order to reduce outcome of short fibers, working parts of the saw gin 4 DP-130 at Uychi cotton plants, Lummus gin at Mirishkor and 3HDD gin at Gulbax cotton plant are needed to explore. The gradual transition of Uzbekistan's cotton plants, which primary process cotton fiber, to a textile cluster will make it possible to conduct a deep analysis that short fibers impact on the cost of produced yarn and thread.

By modernizing and diversifying the industry's machines, our research has shown that it is necessary to determine the reasons for the output of short fibers in saw gins 4 DP-130, 
Lummus and 3HDD and simulate a new experimental design of gin to reduce the output of short fiber fractions.

\section{Reference}

1. J. Boykin et al., Comparison of Five Small-Scale Laboratory Gins to Seven Commercial Gins Sampled Across the Cotton Belt, Beltwide Cotton Conferences, Journal of Cotton Science (2012)

2. D. Whitelock, C. Armijo, G. Gamble, S. D. Hughs P Whitelock, C. B. Armijo, and S. E. Hughs, ENGINEERING AND GINNING Survey of Seed-cotton and Lint Cleaning Equipment in U.S. Roller Gins, Journal of Cotton Science (2013)

3. H.J. Muñoz et al., Procedia Mater. Sci. 9, 123-128 (2015)

4. Sh.M. Azizov, Analysis of the stress state of a two-cylinder saw gin, mexanika muammolari jurnali (2016)

5. A.S. Mamatovich, K. Abdusamat, and P. Arras, World J. Mech. 03(01), 58-61 (2013)

6. A.S. Mamatovich and K. Abdusamat, World J. Mech. 01(03), 122-126 (2011)

7. J. Clif Boykin and J.C. Boykin, The Effects of Dryer Temperature and Moisture Addition on Ginning Energy and Cotton Properties, Journal of Cotton Science (2015)

8. J.D. Wanjura, K. Baker, E. Barnes, J. D. Wanjura, and E. Barnes, ENGINEERING AND GINNING Harvesting, Journal of Cotton Science (2017)

9. S.M. Azizov, Journal Material Sci. Eng. 2(4) (2013)

10. P. A. Funk, G. R. Gamble, and P. A. Funk, ENGINEERING AND GINNING Fiber Properties of Saw and Roller Ginned Naturally Colored Cottons, Journal of Cotton Science (2016)

11. B.T. Aliyev, A.A. Maxmudov, A.I. Karimov, International Journal of Advanced Science and Technology 29(12s), 1891-1897 (2020)

12. B.T. Aliyev, A.A.Maxmudov, A.I. Karimov, International journal of advanced science and technology 29(9s), 6313-6320 (2020)

13. A.A. Maxmudov, B.T. Aliyev, A. Bobomatov, International Journal of Engineering Research \& Technology (IJERT) 9(02) (2020) ISSN: 2278-0181 